\title{
Prevalence of cagA and vacA Genes in Isolates from Patients with Helicobacter pylori-associated Gastroduodenal Diseases in Recife, Pernambuco, Brazil
}

\author{
Carlos AA Brito/*/+, Lenôra MB Silva/ ${ }^{++}$, Norma Jucá**, Nilma C Leal, \\ Wayner de Souza, Dulciene Queiroz ${ }^{* * *}$, Francisco Cordeiro*, Norma Lucena Silva
}

\begin{abstract}
Departamento de Imunologia, Centro de Pesquisas Aggeu Magalhães-Fiocruz, Av. Moraes Rego, s/n, Campus da UFPE, Cidade Universitária, 50670-420 Recife, PE, Brasil *Departamento de Medicina Interna **Departamento de Patologia, Universidade Federal de Pernambuco, Recife, PE, Brasil ***Laboratório de Pesquisa em Bacteriologia, Faculdade de Medicina, Universidade Federal de Minas Gerais, Belo Horizonte, MG, Brasil
\end{abstract}

Geographical differences in the prevalence of Helicobacter pylori genes and their association with disease severity have been identified. This study analyzes the prevalences of the $\operatorname{cag} A$ gene and alleles of the vac $A$ gene in H. pylori-associated gastroduodenal diseases in isolates from Recife, PE, Brazil. Gastric biopsy of $61 \mathrm{H}$. pyloripositive patients were submitted to DNA extraction and gene amplification by polymerase chain reaction. Among the 61 patients, 21 suffered from duodenal ulcer (DU) and 40 from gastritis $(G T)$. The prevalence of $\mathrm{H}$. pylori strains harbouring the cagA gene was higher in the DU group (90.5\%) than in the GT group (60\%) ( $p=0.02)$. The vac $A$ gene was amplified in 56 out of 61 biopsies, of which 43 (76.8\%) contained bacteria carrying the s1 allele and 13 $(23.2 \%)$ the s2. However, the prevalence of the vacA s1 genotying was the same in either DU or GT group. The majority of the s1-typed strains, 39 (90.7\%) out of 43, were subtype s1b. In resume there was a strong association between the H. pylori cag $A^{+}$gene and DU. However, there were no differences between the DU and GT groups in relation to the $\operatorname{vac} A s 1$ and $s 2$ alleles distribution, albeit the subtype $s 1 b$ was predominat.

Key words: cagA - vacA- genotype - Helicobacter pylori - Recife - Brazil

Helicobacter pylori is a polyflagellated spiral gramnegative bacterium and the main etiologic agent of duodenal ulcer (DU) (Coghlan et al. 1987, Marshall et al. 1988) and chronic gastritis. It is also associated with the development of MALT lymphoma (Wotherspoon et al. 1993, Zucca et al. 1998) and carcinoma of the stomach (Uemura et al. 2001, Passaro et al. 2002).

It colonizes the stomach of about $50 \%$ of the world's population, having a prevalence of over $70 \%$ in underdeveloped countries (Perez-Perez et al. 1990, Rocha et al. 1992, Souto et al. 1998). The imbalance between the bacterium aggressive factors and the host defence mechanisms leads to the disease in small part of the population.

Two virulence factors are found only in strains regarded as having greater pathogenicity and the ability to lead to the development of disease, namely the protein associated with cytotoxin, cagA, and the vacuolizing cytotoxin, vacA.

The cagA gene represents a marker for the "island of pathogenicity", a $40-\mathrm{Kb}$ genomic region that codifies virulence factors, including one which induces the

This work was supported by a financial aid grant provided by Fiocruz and Proacad-UFPE.

${ }^{+}$Corresponding author. Fax: +55-81-345.32449. E-mail: cbrito@cpqam.fiocruz.br

${ }^{++}$Pibic/CNPq scholarship

Received 19 February 2003

Accepted 10 July 2003 synthesis of IL-8 cytokine (cagE, cagG), a potent inducer of the inflammatory response (Tummuru et al. 1995, Censini et al. 1996, Hsu et al. 2002). The cagA gene-expressing $H$. pylori strains have been more prevalent in those suffering from DU than patients with gastritis (GT) or nonulcerous dyspepsia (NUD) (Cover et al. 1990, Takata et al. 1998, Van Doorn et al. 1998). However, it has been observed some geographic variations on the type of $H$. pylori strains isolated in Houston (US), for instance, where cagA positive are the predominant strain in the population (Graham et al. 1996, Miehlke et al. 1996, Matsukura et al. 1997).

Another virulence factor, the product of the vacA gene, is able to induce vacuolization in eucariotic cells (Leunk et al. 1988). Polymorphism at the signal sequence (s1a, $\mathrm{s} 1 \mathrm{~b}, \mathrm{~s} 1 \mathrm{c}$ or $\mathrm{s} 2$ ) and/or the middle region ( $\mathrm{m} 1$ or $\mathrm{m} 2)$ of the vacA gene generates allelic variations. The s1 type allele is said to be associated with cytotoxic activity and development of peptic DU (Atherton et al. 1997, Evans et al. 1998). A high prevalence of the sla subtype was observed in different regions in the world (Atherton et al. 1995, Ito et al. 1997). A recent publication showed a greater prevalence of subtype s1b in Central and South American countries (Van Doorn et al. 1999, Ashour et al. 2002).

In spite of the efforts in the past decade to prove an association of the infection by different genotype $H$. pylori strains and the development of a specific disease, the findings were not conclusive (Weel et al. 1996, Takata et al. 1998).

In this study the molecular epidemiology of the $H$. pylori-associated disease has been analyzed in patients from the city of Recife, Northeastern Brazil. 


\section{MATERIALS AND METHODS}

Sixty-one $H$. pylori-infected patients with dyspeptic complaints were selected and submitted to upper gastrointestinal endoscopy at the gastroenterology outpatient clinic in the Pernambuco Federal University Hospital. On confirmation of the histology, they were divided into two groups: those with DU and those suffering from GT. The criteria of exclusion was: patients with peptic ulcer presenting haemorrhage at the time of the diagnosis, those suffering from a severe concurrent condition, portal hypertension and those who had taken nonsteroidal anti-inflammatory drugs in the previous four months or undergone any therapy for $H$. pylori eradication.

The study protocol received the approval of the "Ethics in Research Committee" of the Health Science Centre at the Federal University of Pernambuco. The research protocol started after the patients were explained about the project and sign the informed consent form.

Biopsy and histology of the gastric mucosa - Three fragments of the gastric mucosa were removed from both corpus and antrum. One fragment of each was placed in a sterile Eppendorf tube containing a $0.9 \% \mathrm{NaCl}$ solution and frozen at $-70^{\circ} \mathrm{C}$ for further polymerase chain reaction (PCR) analysis. The four remaining fragments were placed in a flask containing $10 \%$ formalin and sent for histopathology. The microscopic identification of the $H$. pylori was performed by Giemsa staining.

Extraction of DNA - The genomic DNA was extracted from the biopsy sample using the Rapidprep Genomic DNA isolation kit for cell and tissue (Pharmacia, US), in accordance with the manufacturer's instructions and stored at $-20^{\circ} \mathrm{C}$.

$P C R$ - The genomic DNA was used as a DNA template for the amplification of the cagA gene fragment by means of the PCR technique with pairs of primers previously described in the literature and shown in Table I. The primers $\mathrm{F} 1$ and $\mathrm{F} 2$ give a $\mathrm{PCR}$ product of $349 \mathrm{bp}$ and were designated P1 (Navaglia et al. 1998). The other pair of primers (HPC1 and HPC2), which were designated P2, amplifies a region of $194 \mathrm{bp}$ (Ito et al. 1997). The PCR was prepared with $1 \mu$ l of template DNA, $100 \mu$ of dNTP, 20 pmol of each primer and 1U of Taq-DNA polymerase (Pharmacia) in $25 \mu$ of PCR solution containing $10 \mathrm{mM}$ tris- $\mathrm{HCl}$ ( $\mathrm{pH} 8.8$ ); $50 \mathrm{mM} \mathrm{KCl} ; 3 \mathrm{mM} \mathrm{MgCl}{ }_{2}$ and $0.1 \mathrm{mg} / \mathrm{ml}$ of bovine serum albumin. The reaction conditions for the cagA gene amplification with both pairs were as follows: 30 cycles with denaturation at $94^{\circ} \mathrm{C}$ for $1 \mathrm{~min}$; annealing temperature at $55^{\circ} \mathrm{C}$ for $1 \mathrm{~min}$ and synthesis at $72^{\circ} \mathrm{C}$ for 1 $\min$.

For the vacA gene typing we performed the PCR with primers specific for its signal sequence. The PCR-product generated by VA1-F and VA1-R primers were 259 bp or $286 \mathrm{bp}$ in size for respectively type $\mathrm{s} 1$ or $\mathrm{s} 2 \mathrm{vac}^{+}$strains. The use of the antisense VA1-R primer with the SS1-F or SS2-F primers render respectively a PCR fragment of 190 bp for sla and $187 \mathrm{bp}$ for $\mathrm{s} 1 \mathrm{~b}$ subtyped $v a c \mathrm{~A}^{+}$strains. The PCR conditions were as follows for the both set of primers used: 30 cycles of denaturation at $94^{\circ} \mathrm{C}$ for $1 \mathrm{~min}$; annealing temperature at $53^{\circ} \mathrm{C}$ for $1 \mathrm{~min}$; and synthesis at $72^{\circ} \mathrm{C}$ for $1 \mathrm{~min}$ (Atherton et al. 1995).

The PCR reaction negative control consisted of the reaction performed without bacterial DNA or human DNA extracted from epidermal biopsies added. Positive control was carried by replacing the $H$. pylori specific primers to that which amplifies the human constitutive $g p d \mathrm{H}$ gene. PCR products were visualized by eletrophoresis on $1.5 \%$ $(\operatorname{cag} \mathrm{A})$ or $2 \%(v a c \mathrm{~A})$ agarose gels stained with ethidium bromide under UV light and photographed with a polaroid film.

Negative controls were as described above. PCR products were visualized by eletrophoresis on $2 \%$ agarose gels stained with ethidium bromide under UV light and photographed with a polaroid film.

Statistical analysis - The Epi-info program, Version 6.04B was used for the statistical analysis. The continuous quantitative variables were represented by mean, standard deviation, minimum and maximum values, using the Student $t$ test for the analysis of significance. The qualitative and discrete variables were represented by absolute frequency (n) and relative frequency (\%) and their significance analyzed using the chi-square test or Fisher's exact test. The level of rejection for the hypothesis of nullity was always less than $0.05 \%$.

TABLE I

List of primers used for amplification of the fragments of the $v a c \mathrm{~A}$ and $c a g \mathrm{~A}$

\begin{tabular}{|c|c|c|}
\hline Primer (Amplified region) & Size & Sequence \\
\hline VA1-F, $\left(\mathrm{s} 1\right.$ and s2) ${ }^{a}$ & 259 and $286 \mathrm{bp}$ & 5'ATGGAAATACAACAAACACAC3' \\
\hline $\mathrm{SS} 1-\mathrm{F},(\mathrm{s} 1 \mathrm{a})^{a}$ & $190 \mathrm{bp}$ & 5'GTCAGCATCACACCGCAAC3' \\
\hline $\mathrm{SS} 3-\mathrm{F},(\mathrm{s} 1 \mathrm{~b})^{a}$ & $187 \mathrm{bp}$ & 5'AGCGCCATACCGCAAGAG3' \\
\hline VA1-R ${ }^{a}$ & & 5'CTGCTTGAATGCGCCAAAC3' \\
\hline $\begin{array}{l}\mathrm{F} 1,(\text { cagA- P1) } \\
\mathrm{B} 1\end{array}$ & 349 bp & $\begin{array}{l}\text { 5'GATAACAGGCAAGCTTTTGAGG3', } \\
\text { 5'CTGCAAAAGATTGTTTGGCAGA3' }\end{array}$ \\
\hline $\begin{array}{l}\mathrm{HPC} 1,(\operatorname{cagA}-\mathrm{P} 2)^{c} \\
\mathrm{HPC}^{c}\end{array}$ & 194 bp & $\begin{array}{l}\text { 5'TCAAATACACCAACGCCTCC3', } \\
\text { 5'AGCTTCTTGTGGGGACAATC } 3 \text { ' }\end{array}$ \\
\hline
\end{tabular}

$a$ : Atherton et al. 1995; $b$ : Navaglia et al. 1998; $c$ : Ito et al. 1997 


\section{RESULTS}

Characteristics of the population - Among 61 patients selected, 21 had DU and 40 GT. Their ages ranged from 16 to 69 years, the mean age being 40.5 years. It was not observed a significative difference on the mean ages in both groups studied. The majority of patients $(77.2 \%)$ were females.

Regard to the patient socioeconomic status, their monthly income ranged from US\$120 to US\$180. The education level of the studied population was in $50 \%$ of the cases incomplete at primary elementary school, of which half were illiterate. The majority lived in a good sanitation condition with $93.7 \%$ having running water and $97.4 \%$ a sewage system. The drinking water was filtered $(71.3 \%)$, tap water $(27.5 \%)$ or from a well $(1.3 \%)$.

$\operatorname{cag} A^{+}$status - All the biopsy samples were submitted to DNA extraction and PCR analysis (Figure). Among the $43 \mathrm{H}$. pylori cag $A^{+}$strains $(70.5 \%$ of total), 31 matched for both set of primers, five strains were only positive for the P1 pair (three with ulcers and two with GT) and seven were only positive for the P2 pair (three with and four without ulcer). Nineteen out of $21(90.5 \%)$ patients with duodenal ulcer were infected by $H$. pylori cagA ${ }^{+}$strains with a significant difference $(\mathrm{p}=0.01)$, when compared with only 24 out of 40 with GT (60\%) (Table II).

$v a c A^{+}$status - The vacA gene was amplified in 56 $(91.8 \%)$ out of the $61 \mathrm{H}$. pylori isolates. Five out of 40 patients with GT group were not amplified. As the initial selection for sampling was the detection of $H$. pylori at histology, it is unlikely that the $H$. pylori DNA was not extracted. Furthermore, there were not PCR inhibitors in the sample preparation, as shown by the amplification of the human constitutive $g p d \mathrm{H}$ gene. Therefore, it was assumed that there were no obstacle to vacA gene amplification if the gene is present.

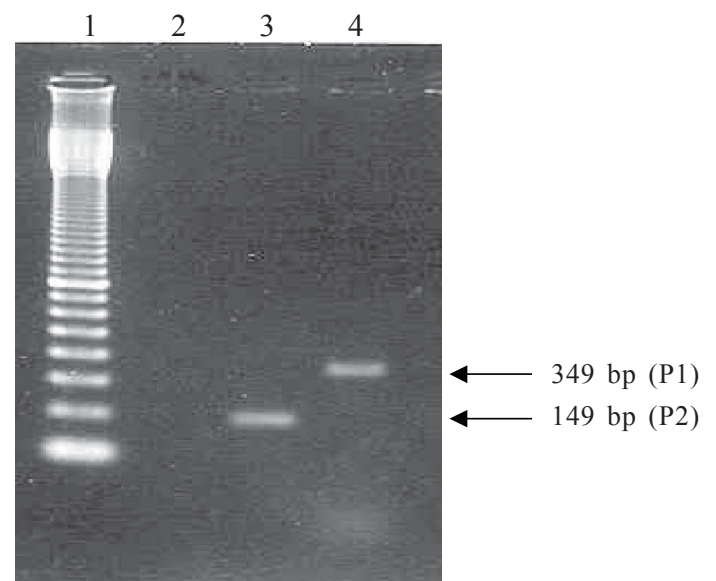

Identification of the cagA by polymerase chain reaction (PCR). Lanes - 1: molecular weight marker; 2: negative control (without DNA); 3: Helicobacter pylori, strain A4 cagA ${ }^{+}$, PCR with primer P2; 4: H. pylori, strain A21 cagA ${ }^{+}$, PCR with primer P1

By means of the signal sequence amplification using different pairs of primers it was possible to classify the strains as type $\mathrm{s} 1$ or s2 and subsequently as subtype s1a or $\mathrm{s} 1 \mathrm{~b}$.

Among the 56 vacA gene-harbouring $H$. pylori isolates, $43(76.8 \%)$ carried s1 and $13(23.2 \%)$ s2 alelles. I $\mathrm{n}$ the DU group, 17 (81\%) isolates were s1 type and four (19\%) s2. Despite of the high percentage it was not statistically different from that found in the GT group, in which $26(74.3 \%)$ isolates were s1 and $9(25.7 \%) \mathrm{s} 2(\mathrm{p}=$ 0.24).

Among the 43 isolates carrying the s1 allele of the vacA gene, 39 (90.7\%) were s 1 b subtype and four (9.3\%) sla, having a similar distribution in both DU and GT groups $(\mathrm{p}>0.2)$ (Table III).

TABLE II

Prevalence ratio of the cagA gene among the patients infected with Helicobacter pylori with endoscopic findings of duodenal ulcer (DU) or gastritis (GT)

\begin{tabular}{lccccc}
\hline & DU & GT & Total & ${\text { PR }\left(\mathrm{CI}_{95 \%}\right)}^{\mathrm{p}}$ \\
\hline Strains cagA $^{+}$ & $19(90.5 \%)$ & $24(60 \%)$ & $43(70.5 \%)$ & $3.98(1.03-15.33)$ & $0.01^{a}$ \\
Strains cagA & & $2(9.5 \%)$ & $16(40 \%)$ & $18(29.5 \%)$ & \\
\hline Total & 21 & 40 & 61 & & \\
\hline
\end{tabular}

a: prevalence ratio (PR) of $H$. pylori ${ }^{+}$cagA gene among patients with DU or GT $\left(\mathrm{PR}=3,98 ; \mathrm{CI}_{95 \%} 1,03-15,33 ; \mathrm{p}=0,01\right)$

TABLE III

Prevalence of the s1, s2, s1a and s1b alleles of the vacA in the strains isolated from patients with duodenal ulcer (DU) and gastritis (GT)

\begin{tabular}{lccccc}
\hline & s1 & s2 & Total & s1a $^{a}$ & \multicolumn{1}{c}{ slb $^{b}$} \\
\hline DU & $17(81 \%)^{a}$ & $4(19 \%)$ & 21 & $1(5.9 \%)$ & $16(94.1 \%)$ \\
GT ${ }^{c}$ & $26(74.3 \%)$ & $9(25.7 \%)$ & 35 & $3(11.5 \%)$ & $23(88.5 \%)$ \\
\hline Total & $43(76.8 \%)$ & $13(23.2 \%)$ & 56 & $4(9.3 \%)$ & $39(90.7 \%)$ \\
\hline
\end{tabular}

a: prevalence ratio (PR) of Helicobacter pylori ${ }^{+}$allele $\mathrm{s} 1$ of the vacA among patients with $\mathrm{DU}$ or GT $\left(\mathrm{PR}=1.09 ; \mathrm{CI}_{95 \%} 0.82-1.45\right.$; $\mathrm{p}=0.41) ; b$ : PR of $H$. pylori ${ }^{+}$allele $\mathrm{s} 1 \mathrm{~b}$ of the vacA gene among patients with DU or GT $\left(\mathrm{PR}=1.06 ; \mathrm{CI}_{95 \%} 0.89-1.28 ; \mathrm{p}=0.47\right)$; $c$ : five samples from GT group were not amplified 
Association of the vacA and the cagA gene-Among the 43 isolates of the vacA s1 allele-carrying $\mathrm{H}_{\text {. pylori }}{ }^{+}$, $33(76.6 \%)$ were $\operatorname{cagA}{ }^{+}$while nine out of the $13(69.2 \%)$ s2 allele-carrying $\mathrm{H}_{\text {. pylori }}{ }^{+}$were also $\mathrm{cagA}^{+}(\mathrm{p}=0.58)$. Considering the vacA subtyping, there were $39-v a c \mathrm{~A}^{+}$ s1b-carrying strains, in which 31 were also cag $\mathrm{A}^{+}$. The small number of the $v a c \mathrm{~A}^{+}$sla allele-carrying strains made it impossible to compare the two populations prevalence ratio (PR) for the cagA gene presence among carriers of the vacA gene $\left(\mathrm{PR}=1.11 ; \mathrm{CI}_{95 \%} 0.74-1.65 ; \mathrm{p}=\mathrm{NS}\right)$

\section{DISCUSSION}

In the present study a higher prevalence of the $\operatorname{cagA}$ gene was observed in patients with DU $(90.5 \%)$ when compared with the GT group (60\%). Several studies have been shown a prevalence of the cagA gene in $H$. pylori isolates from patients with DU ranging from 80 to $100 \%$ (Cover et al. 1990, Weel et al. 1996, Van Doorn et al. 1998, Uemura et al. 2001). Geographical differences, however, have been found. It has been reported in west countries a presence of cagA gene in $95 \%$ of the H. pylori-infected patients with DU, which did not differ significantly from the GT group with a prevalence of $80 \%$ (Miehlke et al. 1996). The same was published for east countries, where the cagA gene-expressing H. pylori was found in $89.3 \%$ of the 28 isolates from patients with DU and in $92.3 \%$ of the 24 with GT (Matsukura et al. 1997). Studies carried out in Houston showed also similar results (Graham et al. 1996).

A Brazilian study from the southeastern state of Minas Gerais showed a cagA gene prevalence of $52.4 \%$ in $21 \mathrm{H}$. pylori isolates from patients with GT and of $88 \%$ in isolates from patients with DU, which were similar to the results presented here (Ashour et al. 2002).

The vacA s1 allele-carrying $H$. pylori was predominantly detected in the isolates. Despite its greater prevalence in DU-patient isolates, there was no significant differences when compared with the GT group. A study in Tennessee showed a strong association of the vacA s1 allele-harbouring $H$. pylori and ulcer, having been detected in 21 out of 23 isolates from patients with DU (91\%) and in only 16 out of 33 of those with GT (48\%), while the vacA s2 allele was found in only $11 \%$ of $19 \mathrm{H}$. pylori-infected patients with ulcer (Atherton et al. 1995).

The prevalence of the different $v a c \mathrm{~A}$ alleles has been reported in $H$. pylori isolates from different regions. A high prevalence of $v a c \mathrm{~A}$ s1 allele and its uniform distribution among the various diseases has been observed in Asian countries (Ito et al. 1997).

In the Brazilian study from Minas Gerais, published in 1998 , it was found a prevalence of $94 \%$ for the s1 vacA allele-harbouring $H$. pylori isolates in patients with DU, much higher than the 54\% found in patients with GT and thus, an association of s1 allele with DU (Evans et al. 1998). Similar results were showed in 2002 by the same researcher group (Ashour et al. 2002). The results presented here suggest the existence of regional differences on the $H$. pylori isolates in this country.

The s $1 \mathrm{~b}$ allele-harbouring $H$. pylori predominated in our study $(90.7 \%)$ and were equally found in isolates from both DU and GT patient groups. The s $1 \mathrm{~b}$ subtype $v a c \mathrm{~A}^{+}-$ H. pylori strains $(89.7 \%$ ) was also predominante in isolates from Portuguese patients (Van Doorn et al. 1998). Another study showed a high prevalence of sla allele (88.8\%) among $170 \mathrm{~s} 1$ vacA allele-harbouring $H$. pylori isolates from Northern and Western Europe, while the isolates from Central and South America were almost complete of the slb subtype. There were other countries with more uniform distribution between the sla and $\mathrm{s} 1 \mathrm{~b}$ subtypes of vac $\mathrm{A}^{+}-H$. pylori strains (Van Doorn et al. 1999). Recently, it was found the vacA s1b allele in 82-H. pylori isolates in Minas Gerais, which was similar to our findings (Ashour et al. 2002).

The association of high prevalence of cagA geneharbouring $H$. pylori and disease severity as DU were showed and are in concordance with several published works. Nevertheless, it is also found in isolates from patients with mild diseases as GT suggesting that cagA gene might be not a specific marker for severity. Futhermore, the inherent genetic polymorphism of regional strains was showed by the differential cagA primer annealing and amplification. It was found in $28 \%$ of the cagA-carrying $H$. pylori strains a discordance on the amplification results generated by the two sets of primers used. We had also observed that few isolates showing multiple vacA genotypes. The same was observed in isolates from Portugal were the prevalence of $H$. pylori infection in adult population is also high (80\%). Nevertheless, we were not able to correlate the infection by multiple vacA genotype $H$. pylori and disease severity.

After the $H$. pylori genome sequencing, it is now expected that other genes be characterized. It might be possible that an association of expressed genes are necessary for the development of specific pathologies and the differential gene expression would characterize the $H$. pylori virulence. This would explain the difference in strain virulence isolated from different parts of the world. Once a molecular marker for $H$. pylori infection severity been described it may be use to help decision on treating some patients.

\section{REFERENCES}

Ashour AAR, Magalães PP, Mendes EM, Collares GB, Gusmão VR, Queiroz DMM, Nogueira AMMF, Rocha GA, Oliveira CA 2002. Distribution of vacA genotypes in Helicobacter pylori strains isolated from Brazilian adult patients with gastritis, duodenal ulcer or gastric carcinoma. FEMS Immunol Med Microbiol 33: 173-178.

Atherton JC, Cao P, Peek RMJr, Tumuru MKR, Blaser MJ, Cover TL 1995. Mosaicism vacuolating cytotoxin alleles of Helicobacter pylori: association of especife vacA types with cytotoxin production and peptic ulceration. J Biol Chem 270: 17771-17777.

Atherton JC, Peek RMJr, Tham KT, Cover TL, Blaser MJ 1997. Clinical and pathological importance of heterogeneity in $v a c \mathrm{~A}$, the vacuolating cytotoxin gene of Helicobacter pylori. Gastroenterology 112: 92-99.

Censini S, Lange C, Xiang Z, Crabtree JE, Ghiara P, Borodovsky M, Rappuoli R, Covacci A 1996. cag, a pathogenicity island of Helicobacter pylori, encodes type I-specific and diseaseassociated virulence factors. Proc Nat Acad Sc USA 93: 14648-14653.

Coghlan JG, Gilligan D, Hunphries H, Mckenna D, Dooley C, Sweeney E, Keane C, O’Morain C 1987. Campylobacter pylori and recurrence of duodenal ulcer - A 12 months follow- 
up study. Lancet ii: 1109-1111.

Cover TL, Dooley CP, Blaser MJ 1990. Characterization of human serologic response to proteins in Helicobacter pylori broth culture supernatants with vacuolizing cytotoxin activity. Infect Immun 58: 603-610.

Evans DG, Queiroz DMM, Mendes EN, Evans DJ 1998. Helicobacter pylori cagA status and $\mathrm{s}$ and $\mathrm{m}$ alleles of vacA in isolates from individuals with a variety of $H$. pyloriassociated gastric diseases. J Clin Microbiol 36: 3435-3437.

Graham DY, Genta RM, Graham DP, Crabtree JE 1996. Serum CagA antibodies in asymptomatic subjects and patients with peptic ulcer: lack of correlation of $\mathrm{IgG}$ antibody in patients with peptic ulcer or asymptomatic Helicobacter pylori gastritis. J Clin Pathol 49: 829-832.

Hsu P, Hwang I, Cittely D, Lai K, El-Zimaity HMT, Gutierrez O, Kim JG, Osato MS, Graham DY, Yamamoto Y 2002. Clinical presentation in relation to diversity within the Helicobacter pylori cag pathogenicity island. $\mathrm{Am} \mathrm{J}$ Gastroenterol 97: 2231-2238.

Ito Y, Azuma T, Ito S, Miyaji H, Hirai M, Yamazaki Y, Sato F, Kato T, Kohli Y, Kuriyama M 1997. Analysis and typing of the vacA gene from cagA-positive strains of Helicobacter pylori isolated in Japan. J Clin Microbiol 35: 1710-1714.

Leunk RD, Johnson PT, David BC, Kraft WG, Morgan DR 1988. Cytotoxic activity in broth-culture filtrates of Campylobacter pylori. J Med Microbiol 26: 93-99.

Marshall BJ, Goodwin CS, Warren JR, Murray R, Blincow ED, Blackbourn SJ, Phillips M, Waters TE, Sanderson CR 1988. Prospective double-blind trial of duodenal ulcer relapse after eradication of Campylobacter pylori. Lancet 2: 14371442.

Matsukura N, Onda M, Kato S, Hasegawa H, Okawa K, Shirakawa T, Tokunaga A, Yamashita K Hayashi A 1997. Cytotoxin genes of Helicobacter pylori in chronic gastritis, gastroduodenal ulcer and gastric cancer: an age and gender matched case-control study. Jpn J Cancer Res 88: 532-536.

Miehlke S, Kibler K, Kim JG, Figura N, Small M, Graham DY, Go MF 1996. Allelic variation in the cagA gene of Helicobacter pylori obtained from Korea compared to the United States. Am J Gastroenterol 91: 1322-1325.

Navaglia F, Basso D, Piva MG, Brigato L, Stefani A, Dal Bó N, Di Mario F, Rugge M, Plebani M 1998. Helicobacter pylori cytotoxin genotype is associated with peptic ulcer and influences serology. Am J Gastroenterol 93: 227-230.

Passaro D J, Chosy EJ, Parsonnet J 2002. Helicobacter pylori: consensus and controversy. Clin Infect Dis 35: 298-304.

Perez-Perez GI, Taylor DN, Bodhidatta L, Wongsrichanalai J, Baze WB, Dunn BE, Echeverria PD, Blaser MJ 1990. Soroprevalence of Helicobacter pylori in Thailand. J Infect
Dis 161: 1237-1241.

Rocha GA, Queiroz DMM, Mendes EN, Oliveira AMR, Moura SB, Barbosa MT, Mendes CC, Lima GF, Oliveira CA 1992. Indirect immunofluorescence determination of the frequency of anti-H. pylori antibodies in Brazilian blood donors. Braz J Med Biol Res 25: 683-689.

Souto FJD, Fontes CJF, Rocha GA, Oliveira AMR, Mendes EN, Queiroz DMM 1998. Prevalence of Helicobacter pylori infection in a rural area of the state of Mato Grosso, Brazil. Mem Inst Oswaldo Cruz 93: 171-174.

Takata T, Fujimoto S, Anzai K, Shirotani T, Okada M, Sawae Y, Ono J 1998. Analysis of the expression of cagA and vacA and vacuolating activity in 167 isolates from patients with either peptic ulcers or non-ulcer dyspepsia. Am J Gastroenterol 93: 30-34.

Tummuru MKR, Sharma SA, Blaser MJ 1995. Helicobacter pylori pic $\mathrm{B}$, a homologue of the Bordetella pertussis toxin secretion protein, is required for induction of IL-8 in gastric epithelial cells. Mol Microbiol 18: 867-876.

Uemura N, Okamoto S, Yamamoto S, Nobutoshi M, Yamaguchi S, Yamakido M, Taniyama K, Sasaki N, Schlemper RJ 2001. Helicobacter pylori infection and the development of gastric cancer. New Engl J Med 345: 784-789.

Van Doorn LJ, Figueiredo C, Pena S, Midolo P, Queiroz DMM, Carneiro F, Vanderborght B, Pegado MGF, Sanna R, Boer W, Schneeberger PM, Correa P, Enders KWNG, Atherton J, Blaser MJ, Quint WG 1999. Geographic distribution of vacA allelic types of Helicobacter pylori. Gastroenterology 116: 823-830.

Van Doorn LJ, Figueiredo C, Rossau R, Jannes G, Van Asbroeck M, Sousa JC, Carneiro F, Quint WGV 1998. Typing of Helicobacter pylori vacA gene detection and cagA gene by PCR and reverse hybridization. J Clin Microbiol 36: 1271-1276.

Weel JFL, Van Der Hulst RWM, Gerrits Y, Roorda P, Feller M, Dankert J, Tytgat GN, Van Der Ende A 1996. The interrelationship between cytotoxin-associated gene A, vacuolating cytotoxin, and Helicobacter pylori-related diseases. J Infect Dis 173: 1171-1175.

Wotherspoon AC, Doglioni C, Diss TC, Pan L, Moschini A, Boni M, Isaacson PG 1993. Regression of primary lowgrade B-cell gastric lymphoma of mucosa-associated lymphoid tissue type after eradication of Helicobacter pylori. Lancet 342: 575-77.

Zucca E, Bertoni F, Roggero E, Bosshard G, Cazzaniga G, Pedrinis E, Biondi A, Cavalli F 1998. Molecular analysis of the progression from Helicobacter pylori-associated chronic gastritis to mucosa-asociated lymphoid-tissue lymphoma of the stomach. New Engl J Med 338: 804-810. 